\title{
ANALYSIS OF FACTORS AFFECTING RICE IMPORTS IN INDONESIA
}

\author{
Kurniawan Putra*, Safrida, Mustafa \\ Syiah Kuala University, Indonesia \\ *E-mail: putra.son63@Gmail.com
}

\begin{abstract}
Indonesia is an agricultural country with a large portion of its income derived from rice farming. However, Indonesia still imports rice from abroad, even exceeding 1 million tons in 2016. The purpose of this study analyzes the variables of domestic rice productivity, domestic rice demand, domestic rice prices, foreign rice prices and foreign exchange rates that affect Indonesian imports. The analytical method used is an explanatory method to test the hypothesis of a simultaneous relationship between the variables studied. The model in this study uses simultaneous models with two stage least square (2SLS). The results showed that domestic demand for rice and domestic rice prices had a positive effect on imports. Meanwhile, domestic rice productivity, prices of foreign rice and foreign exchange rates have a negative effect on rice imports.
\end{abstract}

\section{KEY WORDS}

Imports, rice, trend, rice productivity.

Food is the main need for humans. Food is one of the needs that must be fulfilled so that one's survival can be maintained. Amang (1995) states that one of the foods that must be fulfilled by humans; especially the population of Indonesia is rice. From the consumer side, the importance of rice is undeniable, namely as the main staple food of the country with a participation rate of rice reaching around $95 \%$, meaning that $95 \%$ of households in Indonesia consumed rice, this participation rate certainly varies from region to region. The need for rice consumption in Indonesia is very high so it is necessary to pay attention to sufficient rice commodities.

The condition of rice consumption in Indonesia increases along with population growth. The need for rice is not only consumed as food but also as raw material for food and nonfood industries, seed consumption and other consumption. Not only as food consumption increases, but rice consumption needs as raw material for food and non-food industries also increase. The increase in domestic rice consumption in addition to the rate of population growth is also due to the shifting of the Indonesian population which was not a consumer of rice into rice consumers. However, as seen in the growth rate of domestic rice consumption each decade has decreased, this shows a shift in consumer tastes from rice to commodities that are more diverse along with the increase in the welfare of the Indonesian population (Kusmana 2017).

In order to meet the consumption needs of rice in Indonesia, various efforts have been made to increase rice production. Achieving sufficient national rice production is very important as one of the factors that influence the realization of national food security. Many programs are discussed by the government to meet food security, especially rice. One of the government's discourses in rice production is giving counseling to farmers about the SRI (System Rice Intensification) planting system. SRI is an innovative rice cultivation technique to increase rice production, with this system it is expected that rice production will increase so that it can meet the food needs of the Indonesian people. Efforts that have been made up to now have been able to increase rice production to 80 million tons in 2018 . Even with the increasingly narrow area of agricultural land does not reduce the amount of rice production. This proves that the efforts that have been made are able to increase rice productivity per hectare (Sato, 2006).

Based on the explanation above, Indonesia has succeeded in implementing a discourse that can increase rice production successfully. The supply of Indonesian rice has 
increased from year to year. This can be indicated the success of the country of Indonesia as a developing country. However, aside from the above facts, the government continues to increase the amount of rice imports.

Table 1 - Indonesian Rice Imports for 2013-2017

\begin{tabular}{ccc}
\hline Year & Import of Rice (Ton) & Growth Ratio (\%/year) \\
\hline 2013 & 472.664 & - \\
\hline 2014 & 844.163 & 33,64 \\
\hline 2015 & 861.601 & 22,15 \\
\hline 2016 & 1.283 .178 & 28,36 \\
2017 & 296.117 & $(8,93)$ \\
\hline
\end{tabular}

Data source: Indonesian Statistics 2018 (processed).

It can be seen that rice imports in Indonesia tend to increase from 2013 to 2016 . This is very contradictory because domestic production has increased which should be able to cope with domestic rice consumption needs. It can be concluded that the higher rice production in Indonesia does not determine the total volume of rice imports in Indonesia in aggregate. Even the volume of Indonesia's rice imports increased along with the increase in rice production. Based on this reality, the authors consider it to examine more deeply. So from that the author wants to do a research entitled "Factors That Affect Imports of Rice in Indonesia".

The purpose of this study is to determine the factors that influence rice imports in Indonesia.

\section{METHODS OF RESEARCH}

Determining the place of research is the country of Indonesia with consideration in aggregate. This research is a time series data in annual form. The time period used in this study began from 2003-2017. The type of data used in this study is categorized as secondary data in the form of time series obtained from several sources by retrieving existing statistical data and other related and necessary documents.

To analyze the factors that influence rice imports in Indonesia in this study using the econometric model by building a system of simultaneous equations. The simultaneous equation model is an equation that has the characteristics of an endogenous variable (dependent variable) in an equation to be an exogenous variable (independent variable) in the other equation system. The common form of simultaneous models with $k$ endogenous variables and $m$ exogenous variables are as follows:

$$
\begin{aligned}
& y_{1}=\beta_{12} y_{2}+\cdots+\beta_{1 k} y_{k}+\delta_{11} x_{1}+\cdots+\delta_{1 m} x_{m}+e_{1} \\
& y_{2}=\beta_{21} y_{1}+\cdots+\beta_{2 k} y_{k}+\delta_{21} x_{1}+\cdots+\delta_{2 m} x_{m}+e_{2}( \\
& y_{2}=\beta_{k 1} y_{1}+\beta_{k 2} y_{2}+\cdots+\beta_{k k-1} y_{k-1}+\delta_{k 1} x_{1}+\cdots+\delta_{k m} x_{m}+e_{k}
\end{aligned}
$$

Where: $y_{1}, y_{2}$ and $y_{k}=$ endogenous variables (where, $k=$ number of endogenous variables); $x_{1}-x_{m}=$ exogenous variable (where, $m=$ number of exogenous variables); $\beta=$ coefficient of endogenous variable; $\delta=$ coefficient of exogenous variable, and $e=$ residual in the equation.

Based on the simultaneous formulation model above, it can be made the following factors that affect imports:

$$
\begin{aligned}
& I M B I t=a 0+a 1 P^{\prime} N_{t}+a 2 D B D N t+a 3 H B D N t+a 4 H B L N t+a 5 N T K t+U 1 t \\
& \text { DBDNt }=b 0+b 1 I M B I t+b 2 H B D N t+b 3 I N C t+b 4 J P I t+U 2 t \\
& \text { HBDNt }=c 0+c 1 I M B I t+c 2 D B D N t+c 3 P P D N t+c 4 S B I t+U 3 t
\end{aligned}
$$

Where: $\mid \mathrm{MBI}=$ Indonesian rice imports (tons); PDN = domestic rice productivity (kw/ha); DBDN = demand for domestic rice (tons); $\mathrm{HBDN}=$ domestic rice price $(\mathrm{Rp} / \mathrm{Kg})$; $\mathrm{HBLN}=$ foreign rice price $(\$ / M T) ; N T K=$ foreign currency exchange rate against rupiah $(\mathrm{Rp} / \$)$; INC = per capita income of the Indonesian population (Rp); JPI = total population of 
Indonesia (soul); PPDN = domestic rice production (tons); $\mathrm{SBI}=$ Indonesian rice stock (tons); $\mathrm{U}=$ annoying variable; $\mathrm{t}=$ period $2002-2016$.

From the above structural equation it is known that the endogenous variable (dependent variable) is IMBI, DBDN and HBDN. Whereas the exogenous variables (independent variables) are PDN, HBLN, NTK, INC, JPI, PPDN and SBI.

The simultaneous equation system that was built and developed in this study was allegedly using the Two-stage Least Squares (2SLS) method, because this method can overcome simultaneous biases. The 2SLS method can be used well in the model that is over identified and exactly identified. Testing the data in this study using the application of Statistics and Data (STATA).

\section{RESULTS AND DISCUSSION}

The decision to import rice in Indonesia is influenced by several factors. The following is the test result of the rice import equation using the STATA application.

Table 2 - Results of Analysis of Factors Affecting Rice Imports in Indonesia

\begin{tabular}{cccc}
\hline Equation & R-sq & F-Stat & P-Value \\
\hline IMBI & 0.7025 & 3.30 & 0.0176 \\
Variable & Coefficient & t-count & P-Value \\
\hline PDN & -528663 & $-1,80$ & 0,083 \\
DBDN & 0.3189964 & 1,09 & 0,285 \\
HBDN & 241,5983 & 0,53 & 0,603 \\
HBLN & $-2248,446$ & $-1,19$ & 0,224 \\
NTK & $-372,4697$ & $-1,82$ & 0,079 \\
Constants & 0,00017 & 2,55 & 0,016 \\
\hline
\end{tabular}

The test results can be included in equation (4). The following is the rice import equation in Indonesia:

IMBIt = 0,00017 - 528663PDNt + 0.3189964DBDNt + 241,5983HBDNt $-2248,446$ HBLNt $-372,4697 N T K t+U 1 t$

Domestic rice productivity variables, prices of foreign rice and foreign exchange rates have a negative effect on rice imports. While the demand for domestic rice and domestic rice prices have a positive effect on rice imports. Based on the P-Value which has a significant effect on rice imports, it is domestic rice productivity and foreign exchange rates.

The demand for rice in Indonesia is quite high considering that rice is one of the staple foods of the Indonesian population. In this study it is estimated that the factors that influence the demand for domestic rice (DBDN) are rice imports in Indonesia (IMBI), domestic rice prices (HBDN), Indonesian income per capita (INC) and Indonesia's population (JPI). The following is the result of testing the demand model for domestic rice using the STATA application.

Table 3 - Results of Analysis of Factors Affecting Rice Demand in Indonesia

\begin{tabular}{cccc}
\hline Equation & R-sq & F-Stat & P-Value \\
DBDN & 0,9618 & 64,60 & 0,0000 \\
Variable & Coefficient & t-count & 0,384 \\
IMBI & $-0,8143945$ & $-0,95$ & 0,181 \\
HBDN & 4089,437 & 1,37 & 0,404 \\
INC & 0,5350132 & 0,85 & 0,106 \\
JPI & $-842,701$ & $-1,67$ & 0,064 \\
Constants & 0,00197 & 1,93 & 0 \\
\hline
\end{tabular}

The test results can be included in equation (5). The following is the rice import equation in Indonesia:

DBDNt $=0,00197-0,8143945 \mathrm{IMBIt}+4089,437 \mathrm{HBDNt}+0,5350132 \mathrm{INCt}-842,701 \mathrm{JPIt}+\mathrm{U} 2 \mathrm{t}$ 
The rice import variable in Indonesia and the population of Indonesia have a negative effect on domestic rice demand. While domestic rice prices and per capita income have a positive effect on domestic rice demand. Based on the P-Value which has a significant effect on the demand for rice, it is the price of domestic rice and the population of Indonesia.

Price is an important thing in the transaction process. The following is the analysis of testing the domestic rice price model using the STATA application.

Table 4 - Results of Analysis of Factors Affecting Rice Prices in Indonesia

\begin{tabular}{cccc}
\hline Equation & R-sq & F-Stat & P-Value \\
\hline HBDN & 0,9908 & 268,84 & 0,0000 \\
Variable & Coefficient & t-count & P-value \\
\hline IMBI & 0,0014032 & 3,21 & 0,003 \\
DBDN & $-0,0012277$ & $-2,51$ & 0,018 \\
PPDN & 0,0011065 & 3,43 & 0,002 \\
SBI & $-0,0002276$ & $-1,34$ & 0,190 \\
Constants & $-13946,61$ & $-17,02$ & 0,000 \\
\hline
\end{tabular}

The test results can be included in equation (6) The following is the equation for domestic rice prices:

$\mathrm{HBDNt}=-13946.61+0.0014032 \mathrm{IMBI}-0.0012277 \mathrm{DBDNt}+0.0011065$ PPDNt $-0,0002276 \mathrm{SBI}+\mathrm{U} 3 \mathrm{t}$

Variable demand for domestic rice and Indonesian rice stocks have a negative effect on rice prices. Whereas rice imports and domestic rice production have a positive effect on rice imports. Based on P-Value, all variables have a significant effect on domestic rice prices.

Based on the results of the analysis above explained some points about rice imports in Indonesia. In table 2 it can be seen that the rice productivity variable has the largest coefficient value in the rice import equation. This shows that rice productivity has an important role for the government in making decisions to import rice. In conditions of diminishing land area it does not make productivity decrease. If in the future Indonesia is able to continue to increase rice productivity, then Indonesia does not need to be a rice importing country or even Indonesia will be self-sufficient in food. Efforts that have been made include intensive counseling to farmers, introduction of methods of planting such as Jajar Legowo and SRI (Systen of Rice Intensification) and the provision of appropriate and balanced fertilizers. Considering rice productivity has a significant relationship with rice imports, it is expected that the government will increase the intensification of agricultural land so that productivity increases.

Based on the comparison of domestic rice prices and foreign rice prices, it can be concluded that the Indonesian state is in dire need of rice imports. Increasing the price of domestic rice by Rp.100 / kg will result in an increase in imports of 24,159 tons. While the increase in the price of foreign rice by $\mathrm{Rp} .100 / \mathrm{kg}$ only reduced rice imports by $1.6 \mathrm{~kg}$. This shows the large number of Indonesians who need imported rice due to the high price of domestic rice. Although there is already the highest retail price setting by the government, there are still many Indonesians who choose imported rice that is relatively cheaper. This is of course bad news for the development of the country of Indonesia. There needs to be a change in the mindset of Indonesian consumers to prefer domestic rice.

For rice prices, it is still difficult to see the causes of price fluctuations. Based on table 4 , there is a significant relationship between rice imports, demand for rice, rice production and rice stock against domestic rice prices. But the magnitude of the effect is very little. This is due to government policy regarding the lowest prices and the highest prices of food commodities in Indonesia, especially the commodity of rice.

Based on BPS data, the demand for rice in Indonesia continues to increase every year. However, rice consumption in Indonesia has decreased in 2017. This is evidenced by the data in table 3 which states that Indonesia's population has a negative effect on domestic rice demand. The reduced level of rice consumption in Indonesia is influenced by the existence of a food diversification program by the government with the aim of changing 
people's mindsets in consuming rice. The population of Indonesia, which used to only consume rice as a staple food, has now begun to consume other commodities such as corn, sweet potatoes, nuts and others. The existence of the program is expected to reduce the demand for rice in the country so that Indonesia does not need to import rice.

\section{CONCLUSION}

Factors of domestic rice productivity and foreign exchange rates have a significant effect on rice imports in Indonesia. Whereas domestic rice prices, foreign rice prices and domestic rice demand do not significantly affect rice imports in Indonesia. Domestic rice demand and domestic rice prices have a positive effect on imports. Meanwhile, domestic rice productivity, foreign rice prices and foreign exchange rates have a negative effect.

It is hoped that the government will continue to improve agricultural policies, especially the commodity of rice.

\section{REFERENCES}

1. Amang, B., 1995. Kebijaksanaan Pangan Nasional. Jakarta: PT. Dharma Karsa Utama.

2. Badan Pusat Statistik Provinsi Aceh. 2018. Statistik Indonesia 2018. BPS Provinsi Aceh.

3. Koutsoyiannis, A. 1977. Theory of Econometrics: An Introductory Exposition of Econometric Methods, 2nd edition. Hongkong: MacMillan Publisher Ltd.

4. Kurniyawan, Hengki. 2013. Faktor-faktor yang mempengaruhi impor beras Indonesia, tahun 1980-2009. Semarang: Universitas Negeri Semarang.

5. Kusmana, Acep, dkk. 2017. Perkembangan Produksi dan Konsumsi Pangan di Indonesia. MPRA Paper No. 79976, posted 2 July 2017

6. Sato, S. dan N. Uphoff. 2006. Raising Factor Productivity in Irrigated Rice Production: Opportunities with The System of Rice Intensification. DISIMP. 